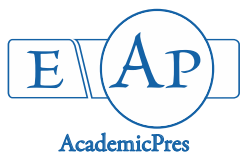

Nwankwo IO et al. (2021)

Notulae Scientia Biologicae

Volume 13, Issue 2, Article number 10866

DOI: $10.15835 / \mathrm{nsb} 13210866$

Research Article

\title{
Prevalence of Campylobacter spp. and antibiotics resistant E. colion poultry carcasses and handlers' hands at Ikpa slaughter, Nsukka, Nigeria
}

\author{
Innocent O. NWANKWO ${ }^{1 *}$, Ekene V. EZENDUKA ${ }^{1}$, \\ John A. NWANTA ${ }^{1}$ Akwoba J. OGUGUA ${ }^{1}$, Benshak J. AUDU ${ }^{2}$ \\ ${ }^{1}$ University of Nigeria, Nsukka, Faculty of Veterinary Medicine, Department of Veterinary Public Health and Preventive Medicine, \\ EnuguState, Nigeriainnocent.nwankwo@unn.edu.ng ("correspondingauthor); ekene.ezenduka@unn.edu.ng; \\ john.nwanta@unn.edu.ng; ogugua.akwoba@unn.edu.ng \\ ${ }^{2}$ National Veterinary Research Institute(NVRI), Biotechnology Division, Vom, Plateau State, Nigeria; benshakng@gmail.com
}

\begin{abstract}
Handling and consumption of contaminated meat can lead to food poisoning and acquisition of antibiotics resistance genes. This study determined the prevalence of Campylobacter spp. and antibiotics resistant E. coli on poultry carcasses and handler's hands at Ikpa slaughter, Nsukka. Swabs collected from carcass surfaces and handler's hands were cultured and isolates were identified with phenotypic and molecular methods. Coliform enumeration, antibiotics susceptibility testing and data analysis were done. Out of 204 samples, 29 (14.2\%) were Campylobacter positive, consisting of $C$. jejuni (27.6\%) and C. coli (72.4\%) while another 67 samples yielded $23(34.4 \%)$ positive E. coli. Coliform counts were $3.2 \times 10^{3} \mathrm{cfu} \mathrm{cm}^{-2}$ and $1.06 \times 10^{3} \mathrm{cfu}$ $\mathrm{cm}^{-2}$ for unwashed and washed carcasses, $2.5 \times 10^{5} \mathrm{cfu} \mathrm{cm}^{-2}$ and $0.5 \times 10^{4} \mathrm{cfu} \mathrm{cm}^{-2}$ for unwashed and washed handlers' hands respectively. E. coli was isolated from 45 and $22 \%$ of unwashed and washed carcasses respectively and Campylobacter from 16\% of unwashed carcasses only. One and five sticks swabbing methods yielded $E$. coli in 20.5 and $60.9 \%$ and Campylobacter in 12 and $83.3 \%$ of carcass samples respectively. Only $E$. coli was detected in 10 (90.0\%) of the unwashed hands. E. coli isolates were multi drug-resistant at $80 \%$ with index $>0.2$ and a range of $70-100 \%$ resistant to enrofloxacin, tetracycline, erythromycin, streptomycin and ampicillin; 30 - 50\% to gentamycin, chloramphenicol and ciprofloxacin while; $10 \%$ were to cephtriazone and amoxicillin/clavulanic acid. Prevalence of Campylobacter and antibiotics resistant E. colispp. were significantly associated $(\mathrm{P}<0.05)$ with status of processor's hands and swabbing methods hence, the public health risk and the need for improved hygiene.
\end{abstract}

Keywords: antibiotics resistant; Campylobacterspp.; E. coli; humans; poultry; zoonosis

\section{Introduction}

Campylobacter and E. coli species are among the leading causes of food borne illnesses worldwide (Altalhi et al., 2010; Colles et al., 2016). Different species of thermotolerant Campylobacter, particularly $C$. jejuni and C. coli as well as antibiotics resistant E. coli and Shiga-toxin producing strains have been isolated in

Received: 18 Dec 2020. Received in revised form: 10 May 2021. Accepted: 28 May 2021. Published online: 02 Jun 2021.

From Volume 13, Issue 1, 2021, Notulae Scientia Biologicae journal uses article numbers in place of the traditional method of continuous pagination through the volume. The journal will continue to appear quarterly, as before, with four annual numbers. 
animals and food of animal origin (Lindqvist and Lindblad, 2008; Altalhi et al., 2010; Made et al., 2017). Chicken is one of the highly consumed meat products across the globe, in most of the countries, it is considered among the most affordable poultry species that are slaughtered at home or the slaughterhouses especially during festivity periods (Mpundu et al., 2019). However, it serves as reservoir hosts for Campylobacter and E. coli species hence, contact and consumption of contaminated poultry have been the most frequently reported risk factor for the infections in humans (Altalhi et al., 2010; Levallois et al., 2014). This can occur mostly during poultry processing in the slaughterhouses as a result of carcasses having contact with fecal materials, contaminated equipment, tables and as well, cross contamination from workers (Zailani et al., 2016). Different prevalence rates of Campylobacterspecies in poultry products at both the slaughter unit and retail outlets have been reported (Rodrigo et al., 2005; Rosenguist et al., 2006). The ingestion of Campylobacter cells as few as 500 cells in a contaminated meat can lead to campylobacteriosis hence, the inclusion of the agent in the European Directive 2003/99/EC on monitoring of zoonotic agents at all levels of the food chain (Anonymous, 2003). The species have caused about 2.5 million cases of food poisoning in USA (CDC, 2010). The UK, Food Standards Agency (FSA) has reported 72.9\% Campylobacter species prevalence and more than 10,000 CFU g ${ }^{1}$ in fresh whole retail chickens (FSA, 2014). On the other hand, E. coli species which are usually used as an indicator of feacal contamination and in the assessment of hygienic practices in abattoirs, have been found in poultry meat at different prevalence rates but more in developing countries including India with $98 \%$ (Sharma et al., 2015).

E. coli contaminated poultry meats could serve as a foremost threat to human health through the transfer of antibiotics resistant gene to other bacteria of clinical importance. Moreover, the survival ability of E. coli as common flora in gut of both animals and humans has outfitted it as a vehicle for such transfer and this is of grave consequences especially if the pathogens are of high virulence (Schroeder et al., 2004). This is added to the fact that antibiotics are wrongly used in the developing countries where resistance have been related with prophylactic usage, wrong dosage, substandard drugs and absence of regulation and control (Nwankwo et al., 2018; Aworh et al., 2019). In Nigeria, out of 66\% antibiotics prescription rate, only $1.2 \%$ was done according to treatment guidelines (Olayinka et al., 2020). Moreover, cephalosporins which has been classified among the critically important antibiotics in humans, also used in poultry, was the most prescribed class (WHO, 2017; Olayinka et al., 2020). This could lead to high selection pressure on the entero-bacteria like E. coli which has a broad range of both pathogenic and commensal strains that can harbor antibiotic resistance traits of public health interest (Van den Bogaard et al., 2001; Nsofor et al., 2013). In Saudi Arabia, high antibiotics resistance rates of 78.4\%, 70.3\%, 48.6\% against Ampicillin, Nalidixic acid and streptomycin respectively have been reported among $E$. coli species from poultry (Altalhi et al., 2010) and among poultry farmers and processors (Van den Bogaard et al., 2001). Nsofor et al. (2013) had also reported high prevalence of antibiotic resistant E. coli in both humans (85.7\%) and animals (53.5\%) which were related to over dependence on antibiotics in poultry production. Moreover, there are potentials for cross-contamination between raw meats and individuals or surfaces in the kitchen environment and the subsequent risk of contamination in ready-to-eat foods as well as transfer of resistant genes to humans through contacts and dietary exposure (Humphrey et al., 2001; Luangtongkum et al., 2009).

Food borne infections caused by Campylobacter and $E$. colispecies are among the most common public health issues with grave consequences including acute gastroenteritis and other complications. However, the epidemiology of the infections as well as spread of antibiotics resistance species via handling of raw meat poultry have not been fully elucidated (Burgess et al., 2005). The study therefore, was aimed at determining the prevalence of Campylobacter species and antibiotics resistant $E$. coli on poultry carcasses and handler's hands at Ikpa slaughter, Nsukka, Nigeria. 


\section{Materials and Methods}

\section{Studyarea}

The study was conducted in Nsukka which is located at coordinates of $6^{\circ} 51^{\prime} 24^{\prime \prime} \mathrm{N}$ and $7^{\circ} 23^{\prime} 45^{\prime \prime} \mathrm{E}$ (Obiorah et al., 2016). It has a tropical climate that support livestock farming. It has 3 slaughterhouses; Ikpa, Orba and Obollo. The Ikpa slaughter which was used in the study serves as the major converging point for the household communities who either sell or buy chicken for local consumption. Majority of the processed chicken are transported to the neighboring state of Kogi, where they are used for different food delicacies and in the preparations of commercial chicken 'suya' (Figure 1).

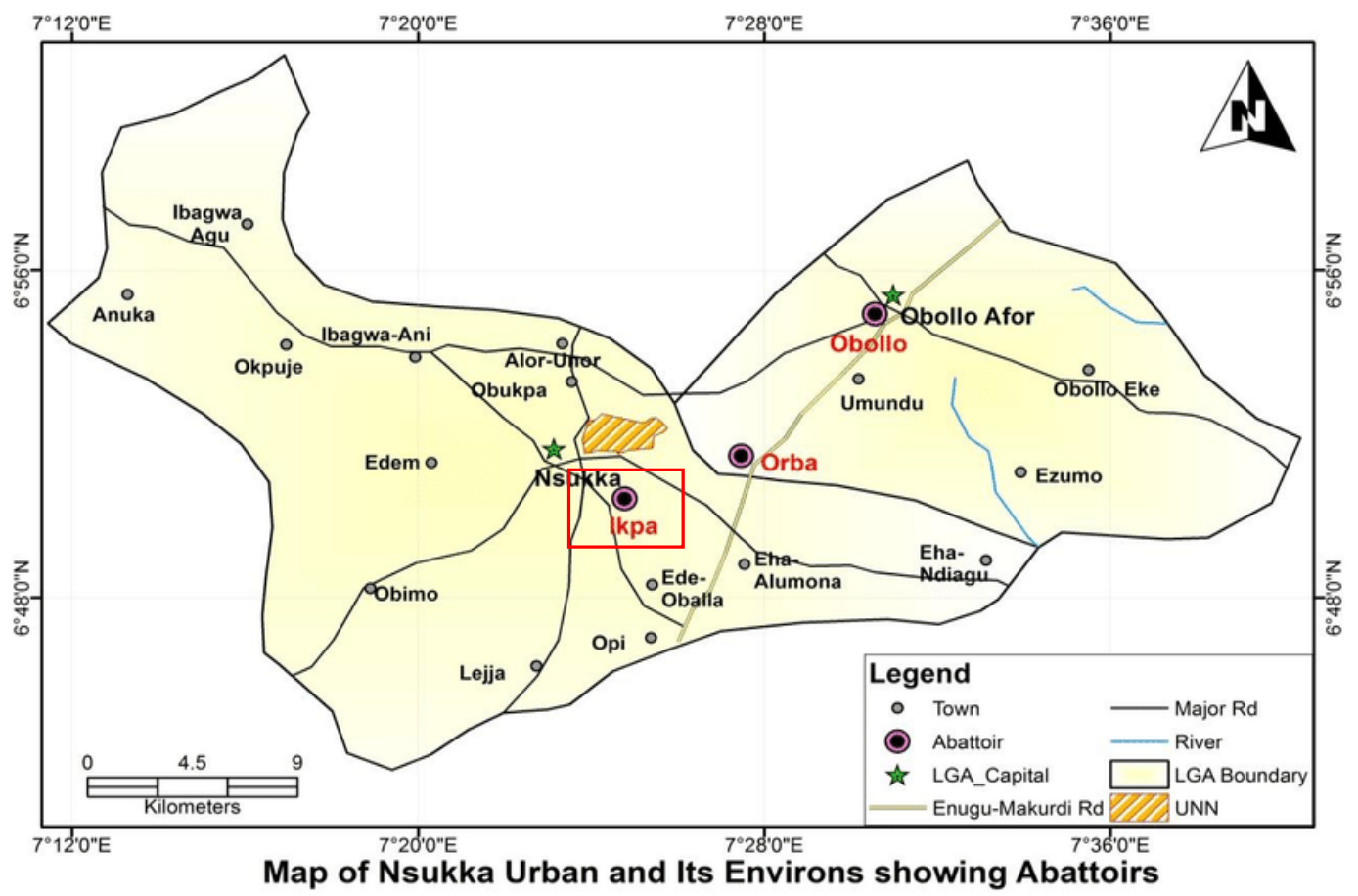

Figure 1. Map of Nsukka urban with red rectangle showing the study site (Ikpa slaughter)

Source: Modified from Obiorah et al. (2016)

\section{Sample size determination}

The minimum sample size was calculated for E. coli and Campylobacter spp. respectively using the formula $\mathrm{N}=\mathrm{Z}^{2} \mathrm{p}$ (1-p)/d2 (Thrusfield, 2005). Where: $\mathrm{N}=$ Sample size; $\mathrm{Z}=1.96$ (Standard error), $\mathrm{d}=$ Level of precision (5\%), $\mathrm{P}=12.75 \%$ and $4.1 \%$ (known prevalence for Campylobacter and $E$. coli species) respectively (Braide et al., 2017; Chah et al., 2018). A minimum sample size of 170 and 60 were for Campylobacter and $E$. colispecies respectively as shown below; Campylobacter $=3.841 \times 0.1275 \times 0.8725 / 0.0025=170$ samples, $E$. coli $=3.8416 \times 0.041 \times 0.959 / 0.0025=60$ samples. However, in order to increase the level of precision, 204 and 67 carcass swabs were used for Campylobacter and $E$. coli species respectively while 22 hands surface swabs of processors that volunteered were equally assessed.

\section{Sampling and sample collection}

Visits were made to the Ikpa slaughter and 5 carcasses (unwashed with water and washed) were systematically ( 1 in 5) sampled every 2 weeks during poultry processing from May to November 2019. Five sterile swab sticks per carcass were rubbed firmly with slow rotation at 5 sites on each carcass covering a total area of $4 \mathrm{~cm}^{2}$ including the skin of the neck and each suspended in $5 \mathrm{ml}$ of peptone water. Swabs were equally 
obtained using one sterile swab stick per carcass as in the processors' hands. The samples were transported in an ice packed container within $2 \mathrm{~h}$ of collection to the Dept. of Veterinary Public Health and Preventive Medicine Lab, University of Nigeria, Nsukka where the samples were processed.

\section{Phenotypic identification}

For Campylobacter, samples were cultured on modified charcoal, cefoperazone deoxycholate agar (CCDA) with selective supplement, (Oxoid, Basingstoke, $\mathrm{UK}$ ) at $42^{\circ} \mathrm{C}$ for $48 \mathrm{~h}$ under microaerobic condition generated by Campygen ${ }^{\mathrm{R}}$ (Oxoid). Pure colonies appearing discrete, whitish and glistening were further subjected to biochemical analysis as previously described (Nwankwo et al., 2017). For E. coli, suspected colony growths on MacConkey agar (Oxoid) were selected and purified by sub culturing aerobically on MacConkey agar (Oxoid) at $37^{\circ} \mathrm{C}$ for $24 \mathrm{~h}$. Pure typical colonies were then inoculated on eosin methylene blue agar (EMB) (Oxoid, England) for isolation of greenish metallic sheen colonies.

\section{Total coliform count}

Samples in $5 \mathrm{ml}$ peptone water were pulled together and tenfold dilution was made by dispensing $1 \mathrm{ml}$ into a tube containing $9 \mathrm{ml}$ of peptone water and subsequently till the tenth $\left(10^{-1}\right.$ to $\left.10^{-10}\right)$. The diluted samples $(0.1 \mathrm{ml})$ were inoculated on MacConkey agar (Oxoid) and incubated aerobically at $37^{\circ} \mathrm{C}$ for $24 \mathrm{~h}$. The population of the lactose fermenters appearing as pinkish colonies was determined by counting the colony forming unit $\left.(\mathrm{cfu} \mathrm{m})^{-1}\right)$ with colony counter and the mean recorded $\left(\mathrm{cfu} \mathrm{cm}^{-2}\right)$.

\section{Storage of isolates}

Campylobacter isolates were kept in storage media (85\% tryptone soya broth and $15 \%$ glycerol) at -20 ${ }^{\circ} \mathrm{C}$ prior to Polymerase Chain Reaction (PCR) analysis while pure colonies of $E$. coli were selected from individual samples and plated on nutrient agar slant prepared overnight and incubated at $37^{\circ} \mathrm{C}$ for $24 \mathrm{~h}$, before storage at $4{ }^{\circ} \mathrm{C}$ (Nwankwo et al., 2017).

\section{Identification by Multiplex PCR}

The genomic DNAs were extracted from the harvested cells of individual colony cultures using the Chelex extraction method. Briefly; harvested cells of each colony were re-suspended in $0.2 \mathrm{ml}(200 \mu \mathrm{l})$ of Phosphate Buffered Saline (PBS), vortexed and centrifuged at $13000 \mathrm{rpm}$ for $15 \mathrm{~min}$. The supernatant was discarded and $200 \mu \mathrm{l}$ of $10 \%$ Chelex suspension was added and incubated at $57^{\circ} \mathrm{C}$ for $15 \mathrm{~min}$ and vortexed for $10 \mathrm{sec}$, incubated at $100^{\circ} \mathrm{C}$ for $8 \mathrm{~min}$ and vortexed again for $10 \mathrm{sec}$. It was centrifuged at $13000 \mathrm{rpm}$ for $3 \mathrm{~min}$ and chilled immediately at $-80^{\circ} \mathrm{C}$. The PCR primers (F 5'CCATAAGCACTAGCTAGCTGAT 3') and (R 5'CCA TAA GCA CTA GCT AGC TGAT3') for $C$. jejuni; (F 5' GTAAAACCAAAGCTTATCGTG 3) and (R 5' TCCAGCAATAGTGTGCAATG 3) for C. coli; (F 5' CCCCCTGGACGAAGACTGAC 3') and (R 5' ACCGCTGGCAACAAAGGATA 3') for E. coli (Inqaba Biotechnology Company, Pretoria, South Africa) were used to amplify the 16S rRNA (Moreno et al., 2001; Yamazaki-Matsune et al., 2007). The reaction of each sample was made up with the specific primer pair ( $1 \mu \mathrm{M}$ each primer), $2 \mathrm{X}$ Polymerase Chain Reaction (PCR) Master Mix (QIAGEN), 100 ng of DNA template, and nuclease free water to $25 \mu$. The amplification was done in a DNA thermal cycler (Eppendorf) with an initial denaturation of $1.5 \mathrm{~min}$ at $95^{\circ} \mathrm{C}$, followed by 30 cycles of denaturation $\left(0.5 \mathrm{~min}\right.$ at $\left.95^{\circ} \mathrm{C}\right)$, annealing $\left(0.5 \mathrm{~min}\right.$ at $\left.58^{\circ} \mathrm{C}\right)$, and elongation $\left(0.5 \mathrm{~min}\right.$ at $\left.72^{\circ} \mathrm{C}\right)$ and final extension at $72{ }^{\circ} \mathrm{C}$ for $7 \mathrm{~min}$ (Wang et al., 2002; Nwankwo et al., 2017). Agarose gel (1.5\%) electrophoresis was done in trisboric acid/EDTA (TAE) buffer which contained $5 \mu$ of ethidium bromide ( 5 $\mathrm{mg} / \mathrm{ml}$ ) at 120 volts for 40 mins. Reference strains of E. coli, C. jejuni and C. coli from National Veterinary Research Institute (NVRI) Vom, Plateau State, Nigeria were used as positive controls while sterile water was used as negative control. Band views of 323, 126 and 401 base pairs (bps) for C. jejuni, C. coli and E. coli respectively were visualized using the GelDoc-It ${ }^{\mathrm{mi}} 310$ Imaging System (UVP, Cambridge, United Kingdom). 


\section{Antibiotics susceptibility testing}

Ten antibiotics from eight different classes based on WHO (2017) recommendation list of Critically Important Antimicrobials for Human and animals were used (WHO, 2017). The ten antibiotics were: ampicillin, $10 \mu \mathrm{g}$; ciprofloxacin (CIP), $5 \mu \mathrm{g}$; erythromycin (E), $15 \mu \mathrm{g}$; tetracycline (TE), $30 \mu \mathrm{g}$; gentamicin $(\mathrm{CN}), 10 \mu \mathrm{g}$; streptomycin (S), $10 \mu \mathrm{g}$; enrofloxacin (ENR), $5 \mu \mathrm{g}$; ceftriazone (CEF), $30 \mu \mathrm{g}$; amoxicillin and clavulanic acid (AMC) $30 \mu \mathrm{g}$ and chloramphenicol (CHL) $30 \mu \mathrm{g}$. Representative isolates were subjected to an antibiotic susceptibility test by employing the disc diffusion test method following Clinical and Laboratory Standards Institute (CLSI, 2010). The classifications of the isolates were done as resistant and sensitive. Resistance to $\geq 3$ classes of antibiotics was termed Multidrug Drug Resistance (MDR) (Magiorakos et al., 2012).

\section{Data analysis and interpretation}

An acceptable count of $\leq 10 \mathrm{CFU} \mathrm{\textrm {cm } ^ { - 2 }}(1 \mathrm{log})$ for $E$. coli count was adopted and used in the interpretation of the total coliform count (TCC) (NDVQPH, 2010). The results were presented in tables and Chi-Square was used to analyze the statistical significant relationship between poultry carcass and handlers' hands status, collection methods with contamination of both $E$. coli and Campylobacter spp. at $\mathrm{p} \leq 0.05$. Data analysis was done using Open Epi Statistics (version 3.0) (Centers for Disease Control and Prevention, CDC).

\section{Results}

Out of the 204 and 67 cultured samples, 29 (14\%) and 23 (34.3\%) were positives for Campylobacter and E. coli respectively (Table 1). Of the 29 Campylobacter isolate, 8 (27.6\%) and 21 (72.4\%) were C. jejuni and C. coli respectively. For Campylobacter, 28/189 (14.8\%) and 0/15 were positive in unwashed and washed carcasses respectively while $18 / 40(45 \%)$ and $6 / 27(22 \%)$ were positive for $E$. coli in unwashed and washed carcasses in that order (Table 2).

Table 1. Prevalence of Campylobacter and E. coli isolates on raw poultry carcasses at Ikpa slaughter, Nsukka, Nigeria

\begin{tabular}{|l|c|c|c|c|c|}
\hline \multicolumn{1}{|c|}{ Pathogen (n) } & No negative & No positive (\%) & OR & 95CI & p-value \\
\hline Campylobacter $(204)$ & 175 & $29(14.2)$ & 1 & & \\
\hline E. coli $(67)$ & 44 & $23(34.3)$ & 3.15 & $1.66-5.98$ & 0.00 \\
\hline
\end{tabular}

Table 2. Carcasses hygiene status and the detection of Campylobacter and E. coli isolates at Ikpa, slaughter, Nsukka, Nigeria

\begin{tabular}{|c|c|c|c|c|c|c|}
\hline \multirow{2}{*}{ Pathogen } & Sample source (n) & No +ve (\%) & No -ve & OR & 95\%CI & $\begin{array}{c}\text { p- } \\
\text { value }\end{array}$ \\
\hline \multirow{2}{*}{ E. coli } & $\begin{array}{c}\text { Washed carcass } \\
(27)\end{array}$ & $6(22.22)$ & 21 & 1 & & \\
\cline { 2 - 7 } Campylobacter & $\begin{array}{c}\text { Unwashed carcass } \\
(40)\end{array}$ & $18(45.00)$ & 22 & 2.86 & $0.95-9.61$ & 0.09 \\
\cline { 2 - 7 } & $\begin{array}{c}\text { Washed) carcass } \\
(15)\end{array}$ & 0 & 14 & 1 & & 0.63 \\
\hline
\end{tabular}

Out of the 67 carcass swab samples, 23 were used for coliform count and 17 (73.9\%) had coliform growth at dilution $10^{-3}$ with mean counts of $1.06 \times 10^{2} \mathrm{cfucm}^{-2}$ and $3.2 \times 10^{2} \mathrm{cfu} \mathrm{cm}^{-2}$ for washed and unwashed carcasses respectively. Three out of $10(30 \%)$ of the hand samples used for coliform count had growth with mean counts of $2.5 \times 10^{5} \mathrm{cfu} \mathrm{cm}^{-2}$ (unwashed) and $0.5 \times 10^{4} \mathrm{cfu} \mathrm{cm}^{-2}$ (washed) (Tables 3 and 4). 
Table 3. Total coliform counts of poultry carcass surfaces at Ikpa slaughter, Nsukka, Nigeria

\begin{tabular}{|c|c|c|c|c|c|}
\hline $\begin{array}{c}\text { Numbers for } \\
\text { unwashed } \\
\text { carcass }\end{array}$ & $\begin{array}{c}\text { No of colonies at } \\
10^{-3} \text { dilution }\end{array}$ & $\begin{array}{l}\text { Total coliform } \\
\text { count per } \mathrm{cm}^{2}\end{array}$ & $\begin{array}{c}\text { Number for } \\
\text { Washed carcass }\end{array}$ & $\begin{array}{c}\text { No of colonies at } \\
10^{-3} \text { dilution }\end{array}$ & $\begin{array}{l}\text { Total coliform } \\
\text { count per } \mathrm{cm}^{2}\end{array}$ \\
\hline 1 & 4 & $2.0 \times 10^{3}$ & 15 & 3 & $1.5 \times 10^{3}$ \\
\hline 2 & 11 & $5.5 \times 10^{3}$ & 16 & 0 & 0 \\
\hline 3 & 25 & $1.25 \times 10^{4}$ & 17 & 5 & $2.5 \times 10^{3}$ \\
\hline 4 & 32 & $1.6 \times 10^{4}$ & 18 & 4 & $2.0 \times 10^{3}$ \\
\hline 5 & 12 & $6.0 \times 10^{3}$ & 19 & 4 & $2.0 \times 10^{3}$ \\
\hline 7 & 2 & $1.0 \times 10^{3}$ & 21 & 1 & $5.0 \times 10^{2}$ \\
\hline 8 & 0 & 0 & 22 & 0 & 0 \\
\hline 9 & 0 & 0 & 23 & 0 & 0 \\
\hline 10 & 0 & 0 & Mean & & $1.06 \times 10^{2}$ \\
\hline 11 & 2 & $1.0 \times 10^{3}$ & & & \\
\hline 12 & 1 & $5.0 \times 10^{2}$ & & & \\
\hline 13 & 3 & $1.5 \times 10^{3}$ & & & \\
\hline 14 & 1 & $5.0 \times 10^{2}$ & & & \\
\hline 24 & 1 & $5.0 \times 10^{2}$ & & & \\
\hline 25 & 1 & $5.0 \times 10^{2}$ & & & \\
\hline Mean & & $3.2 \times 10^{2}$ & & & \\
\hline
\end{tabular}

Table 4. Total coliform counts of handlers' hands at Ikpa slaughter, Nsukka, Nigeria

\begin{tabular}{|l|c|c|c|c|c|}
\hline $\begin{array}{c}\text { Numbers for } \\
\text { unwashed } \\
\text { hands }\end{array}$ & $\begin{array}{c}\text { No of colonies } \\
\text { at } 10^{-5} \text { dilution }\end{array}$ & $\begin{array}{c}\text { Total coliform } \\
\text { count per } \mathrm{cm}^{2}\end{array}$ & $\begin{array}{c}\text { Numbers for } \\
\text { Washed hands }\end{array}$ & $\begin{array}{c}\text { No of colonies } \\
\text { at } 10^{-5} \text { dilution }\end{array}$ & $\begin{array}{c}\text { Total coliform } \\
\text { count per } \mathrm{cm}^{2}\end{array}$ \\
\hline 6 & 4 & $2.0 \times 10^{5}$ & 26 & 0 & 0 \\
\hline 20 & 6 & $3.0 \times 10^{5}$ & 27 & 0 & 0 \\
\hline 31 & 0 & 0 & 28 & 0 & 0 \\
\hline 32 & 0 & 0 & 29 & 0 & $0.5 \times 10^{4}$ \\
\hline 33 & 0 & 0 & 30 & 1 & $0.5 \times 10^{4}$ \\
\hline Mean & & $2.5 \times 10^{5}$ & & & 0 \\
\hline
\end{tabular}

Furthermore, $9 / 44(20.5 \%)$ and 14/23 (60.9\%) were positive for $E$. coli in samples collected with one and five sticks/sites swabbing methods respectively, while 24/198 (12\%) and 5/6 (83.3\%) were positive for Campylobacter with the same collection methods in that same order (Table 5). Out of 12 unwashed hands, 10 (83.3\%) were positive for $E$. coli while no positive was recorded from the washed hands even for Campylobacter spp. in both washed and unwashed hands (Table 6).

Table 5. Sample collection techniques and detection of Campylobacter and E. coli isolates on carcasses at Ikpa, slaughter, Nsukka, Nigeria

\begin{tabular}{|l|c|c|c|c|c|c|}
\hline \multicolumn{1}{|c|}{ Pathogen } & $\begin{array}{c}\text { Sampling collection } \\
\text { methods (n) }\end{array}$ & $\begin{array}{c}\text { No +ve } \\
(\%)\end{array}$ & No-ve & OR & 95\%CI & p-value \\
\hline \multirow{2}{*}{ E. coli } & One swab stick (44) & $9(20.45)$ & 35 & 1 & & 0.00 \\
\cline { 2 - 7 } & Five swab sticks (23) & $\begin{array}{c}14 \\
(60.86)\end{array}$ & 9 & 6.0 & $1.99-18.40$ & \\
\hline \multirow{2}{*}{ Campylobacter } & One swab stick (198) & $\begin{array}{c}24 \\
(12.12)\end{array}$ & 174 & 1 & & 0.00 \\
\cline { 2 - 8 } & Five swab sticks (6) & $5(83.33)$ & 1 & 36.2 & $4.06-323.50$ & 0 \\
\hline
\end{tabular}


Table 6. Hand hygiene status and the detection of Campylobacter and E. coli isolates at Ikpa slaughter, Nsukka, Nigeria

\begin{tabular}{|c|c|c|c|c|c|c|}
\hline Pathogen & Sample source $(\mathrm{n})$ & No +ve (\%) & No-ve & OR & $95 \% \mathrm{CI}$ & $\mathrm{p}$-value \\
\hline \multirow{2}{*}{ E. coli } & $\begin{array}{l}\text { Washed human } \\
\text { palms (10) }\end{array}$ & 0 & 10 & 1 & & \\
\hline & $\begin{array}{l}\text { Un washed human } \\
\text { palms (12) }\end{array}$ & $10(83.33)$ & 2 & 27 & $2.34-311.1$ & 0.00 \\
\hline \multirow{2}{*}{ Campylobacter } & $\begin{array}{l}\text { Washed human } \\
\text { palms (10) }\end{array}$ & 0 & 10 & & & \\
\hline & $\begin{array}{l}\text { Un washed human } \\
\text { palms (12) }\end{array}$ & 0 & 12 & & & \\
\hline
\end{tabular}

Out of 20 E. coliisolates, $16(80 \%)$ were resistant to 3 or more antibiotics. A range of $70-100 \%$ resistance was recorded for enrofloxacin (70\%), tetracycline (90\%), erythromycin (100\%), streptomycin (100\%) and ampicillin (100\%). Cephtriazone and amoxicillin/ clavulanic acid had 10\% resistance each followed by ciprofloxacin (30\%), chloramphenicol (40\%) and gentamycin (50\%). The antibiotics resistance profile and multi resistance index are shown in Tables 7 and 8 respectively.

Table 7. Antibiotics resistance profile of $E$. coli isolates from poultry carcass at Ikpa slaughter, Nsukka, Nigeria

\begin{tabular}{|l|c|c|c|c|}
\hline \multicolumn{1}{|c|}{ Classes of antibiotics } & Antibiotics Disk $(\mu \mathrm{g})$ & $\begin{array}{c}\text { E. coli } \\
\text { isolate } \\
\mathrm{N}=20\end{array}$ & $\begin{array}{c}\text { Zone } \\
\text { diameter } \\
\text { breakpoint } \\
(\mathrm{mm}) \mathrm{R}\end{array}$ & $\begin{array}{c}\text { Antibiotics } \\
\text { Resistance in } \\
\%\end{array}$ \\
\hline Fluoroquinolones & Ciprofloxacin (5) & 6 & $\leq 15$ & 30 \\
\hline Macrolides & Erythromycin (15) & 20 & $\leq 13$ & 100 \\
\hline Aminoglycosides & Streptomycin (10) & 20 & $\leq 11$ & 100 \\
\hline Fluoroquinolones & Enrofloxacin (5) & 14 & $\leq 17$ & 70 \\
\hline Penicillin & Ampicillin (10) & 20 & $\leq 13$ & 100 \\
\hline Aminoglycosides & Gentamycin (10) & 10 & $\leq 12$ & 50 \\
\hline Tetracyclines & Tetracycline (30) & 18 & $\leq 14$ & 90 \\
\hline Cephalosporin & Cephtriazone (30) & 2 & $\leq 19$ & 10 \\
\hline $\begin{array}{l}\text { Penicillin/ beta-lactamase } \\
\text { inhibitors }\end{array}$ & Amoxicillin/Clavulanic acid & 2 & $\leq 13$ & 10 \\
\hline Chloramphenicol & Chloramphenicol (30) & 8 & $\leq 12$ & 40 \\
\hline
\end{tabular}

Note: $\mathrm{R}=$ Resistance (CLSI, 2018)

Table 8. Multiple antibacterial resistance patterns and indices of $E$. coli isolates from carcass surface at Ikpa slaughter, Nsukka, Nigeria

\begin{tabular}{|c|c|c|c|c|}
\hline No of antibacterial class & Resistance pattern & $\begin{array}{c}\text { No of resistant } \\
\text { isolates (\%) }\end{array}$ & $\begin{array}{l}\text { Total no of } \\
\text { isolates (\%) }\end{array}$ & $\begin{array}{c}\text { MARI } \\
(\mathrm{a} / \mathrm{b})\end{array}$ \\
\hline 4 & ERY, S, AMP, TET & \begin{tabular}{l|l}
$4(20)$ & \\
\end{tabular} & $20(100)$ & 0.4 \\
\hline 6 & CHL, ERY, S, ENR, CN, TET & $2(10)$ & & 0.6 \\
\hline 9 & CHL, CIP, ERY, S, ENR, AMP, CN, TE & $2(10)$ & & 0.8 \\
\hline 5 & ERY, S, ENR, AMP, TET & $4(20)$ & & 0.5 \\
\hline 6 & ERY, S, ENR, AMP, CN, TET & $2(10)$ & & 0.6 \\
\hline 4 & ERY, S, AMP, AMC & $2(10)$ & & 0.4 \\
\hline 7 & CHL, CIP, ERY, S, ENR, AMP, TET & $2(10)$ & & 0.7 \\
\hline 8 & CHL, CIP, ERY, S, ENR, AMP, CN, TET & $2(10)$ & & 0.8 \\
\hline
\end{tabular}

Note: MARI=Multi Antibiotics resistance Index where $a=$ No of antibiotics an isolate is resistant to. $b=$ Total antibiotics the isolate was subjected to (Aworh et al., 2019). Ampicillin (AMP), $10 \mu \mathrm{g}$; Ciprofloxacin (CIP), $5 \mu \mathrm{g}$; Erythromycin (E), $15 \mu \mathrm{g}$; Tetracycline (TE), $30 \mu \mathrm{g}$; Gentamicin (CN), $10 \mu \mathrm{g}$; Streptomycin (S), $10 \mu \mathrm{g}$; Enrofloxacin (ENR), $5 \mu \mathrm{g}$; Ceftriazone (CEF), $30 \mu \mathrm{g}$; Amoxicillin and Clavulanic acid (AMC) $30 \mu \mathrm{g}$ and Chloramphenicol (CHL) $30 \mu \mathrm{g}$ 


\section{Discussion}

The detection of both Campylobacter and E. colispecies in the study is of great concern as the zoonotic infections has been associated with both public health and economic consequences. The low prevalence rate (14.2\%) for Campylobacterspp. in this study can be explained by the poor viability of the organism outside the poultry gut when compared with the $36 \%$ prevalence reported in poultry feaces in the same study area (Akwuoba et al., 2010). However, the two species; $C$. jejuniand C.coli isolated in the study were the pathogenic strains responsible for severe gastroenteritis and other complications in humans both in the developed and developing countries (Nwankwo et al., 2017; Jovanovic et al., 2020). Higher prevalence rates of Campylobacter species in live chicken have been reported in many other studies including 38.1\% and 39.1\% in Malaysia and Nigeria respectively (Nwankwo et al., 2017; Mohamed-Yousif et al., 2019). Moreover, the lower rate on the surface of processed chicken carcasses could be due to the incompatible atmospheric condition and other surrounding pressures that would have caused them in viable but non culturable (VBNC) state (Magajna and Schraft, 2015).

On the other hand, the high prevalence rate $(34.4 \%)$ for $E$. coli being the most common commensal enteric bacteria in humans and animals has revealed the level of contamination in the slaughterhouse during the poultry processing. Both Campylobacter and $E$. coli are zoonotic pathogens of significant public health concern and their prevalence on the surface of processed carcasses can cause further contamination of meat product and consequential infection in humans (Nwankwo et al., 2017). Even though the $36.4 \%$ prevalence for E. coli was lower than $43.4 \%$ and $47.2 \%$ in retailed poultry and frozen meat in Oyo state, Nigeria and $38.3 \%$ in bison carcasses in USA, it was far higher than $4.7 \%$ and $7.5 \%$ in hatcheries and farms respectively in Zaria, Kaduna state, Nigeria. This implies that less contaminations may have occurred in the farms and hatcheries and has further shown the significance of hygiene in the abattoirs where high contamination rates have also been reported (Qiongzhenet al., 2004; Raji et al., 2007). The prevalence rate was also higher than $12.75 \%$ and $11.1 \%$ reported in processed poultry in neighboring states of Imo and Cross River respectively (Ukut et al., 2010; Braide et al., 2017). This may be a reflection of higher hygiene standard in the abattoirs where those studies were conducted.

Since the study has revealed the Total Coliform Count (TCC) of both poultry carcasses and handlers' hands to be above the $10 \mathrm{CFU} \mathrm{cm}$-2 permissible limits as recommended in the EU Decision 2001/471/EC (MC Evoy et al., 2004; NDVQPH, 2010), there is need for improved hygiene at Ikpa slaughter in order to reduce the high risk of infections among processors and consumers of affected meat. The lower TCC $\left(1.06 \times 10^{2} \mathrm{cfu}\right.$ $\left.\mathrm{cm}^{-2}\right)$ value in the washed carcass compared to $\left(3.2 \times 10^{2} \mathrm{cfu} \mathrm{cm}^{-2}\right)$ in the unwashed has further revealed the need for the use of uncontaminated water in the rinsing of poultry carcasses. It was observed that processors usually use the same water in a washing basin without regular changing throughout the day's operation and as such, could not achieve significant reduction. The poor reduction rate was in agreement with that of the TCC range; 5.0 - 6.3 mean $\log \mathrm{CFU} \mathrm{cm}{ }^{-2}$ before washing and 4.6-6.3 CFU cm$~^{-2}$ after carcass washing in South Africa (Jaja et al., 2018). Improved and significant reduction in the microbial contamination can further be achieved by washing carcasses over portable running water as contamination of drinking water has equally been reported (Cokal et al., 2011). Furthermore, the high TCC value in the unwashed hands could possibly lead to the spread of $E$. coli infection as workers were seen shaking hands, eating and drinking during the abattoir operation (Adugyamfi et al., 2012). The finding of 5 sticks swabbing method as being twice and four times more effective than the one stick swabbing in the isolation process of $E$. coliand Campylobacter species respectively, indicates that multiple swabbing is essential in the detection rate of these pathogens especially Campylobacter species that requires special conditions and capacities (Nwankwo et al., 2017).

The prevalence of antibiotic resistant $E$. coli in this study may be associated with use-selection pressure and this is of great concern due to the public health and economic implications especially in a country where antibiotics are easily acquired and used with bias in poultry (Kabir et al., 2004). The 100\% resistance to AMP, STR and ERY in the study is worrisome since they are used as the first-line agents in the treatment of 
colibacillosis in humans and may lead to narrowed option for therapy (Horner et al., 2013). Indeed, there were increase in the pathogen resistance to AMP and STR compared to $48.6 \%$ and $78.4 \%$ for the antibiotics in that same order as reported in another study (Altalhi et al., 2010). The $90 \%$ resistance for tetracycline was in agreement with other studies that have reported high resistant $E$. colifrom animal origins including $89.63 \%$ in China and 89\% in Tunisia (Soufi et al., 2009; Zhang et al., 2012). Increased resistance from 19 to 30\% for ciprofloxacin and $70 \%$ for enrofloxacin in the study may be due to the continuous use of flouroquinolone in poultry industry which has been banned in the developed world and this could jeopardize antibacterial therapy in humans (Li et al., 2019).

Furthermore, even though the U.S. Food and Drug Administration has prohibited the use of chloramphenicol in food animals, the increased resistance for both chloramphenicol (40\%) and gentamycin (50\%), compared to $32.4 \%$ and $24.3 \%$ in that order as reported in another study can be associated with their uncontrolled uses in developing countries (DHHS, 2010). Amoxicillin/clavulanic acid and cephtriazone had low rates $(10 \%)$ each and this could be ascribed to their low or more recent usage in poultry industry. The above finding was in agreement with the low resistant rate (8.9\%) of E. colito amoxicillin/clavulanic acid in Turkey (Gundogan and Avci, 2013). Many high prevalence of multidrug resistance among E. coli as revealed in the study have been reported in chicken and foods of animal origin (Schroeder et al., 2004; El-Enbaawy and Yousif, 2006). Studies have equally established associations between urinary tract infections and gastroenteritis in humans with the consumption of E. coli and Campylobacter spp. contaminated poultry meat (Manges et al., 2007; Karikari et al., 2017). Hence, there is need for more active surveillance and improved hygiene practices in the slaughterhouses in order to prevent the infections spread and resistant gene transfers to other microbes in the food chain and to humans.

\section{Conclusions}

In conclusion, the prevalence of Campylobacter species and antibiotics resistant E. coli on poultry carcasses as well as handlers' hands as obtained in Ikpa slaughter, Nsukka has revealed the high risk of the infections spread in humans and antibiotics resistance gene transfer among other pathogens of clinical importance through handling and consumption of contaminated poultry meat.

\section{Authors' Contributions}

I.O.N conceptualized and designed the research outline with E.V.E. The investigation was conducted by I.O.N under the supervision of E.V.E and J.A.N. The molecular and data analysis was done by B.J.A. and A.J.O. respectively. The manuscript was drafted by I.O.N and reviewed by all the authors before the submission.

All authors read and approved the final manuscript.

Ethical approval (for researches involving animals or humans)

Ethical clearance was obtained from the Institutional animal care and use committee, Faculty of Veterinary Medicine, University of Nigeria, Nsukka. Poultry processors were informed and hand swabs were collected only from those that gave their consent after the purpose of the study was explained to them. 


\section{Acknowledgements}

Authors are grateful to the union of Ikpa poultry processors for her cooperation during the sample collection at the slaughterhouse. Dr. C. C. Ezeugwu is highly appreciated for his time and kind assistance during the sample collection period. Mr. K. Olorunfemi of Veterinary Pathology and Microbiology Lab, Mrs. S. N. Ikechukwu and Mrs. R. Ugwuanyi of Veterinary Public Health and Preventive Medicine Lab are highly appreciated for their assistance in the Lab. We are equally grateful to Dr. M.U. Anyanwu of the Dept. of Veterinary Pathology and Microbiology for his useful suggestions and the provision of some of the Lab. consumables.

\section{Conflict of Interests}

The authors declare that there are no conflicts of interest related to this article.

\section{References}

Altalhi AD, Gherbawy YA, Hassan SA (2010). Antibiotic resistance in Escherichia coli isolated from retail raw chicken meat in Taif, Saudi Arabia. Food borne Pathogen and Diseases 7(3):281-283. https://doi.org/10.1089/fpd.2009.0365

Adu-gyamfi A, Torgby-tetteh W, Appiah V (2012). Microbiological quality of chicken sold in Accra and determination D10-Value of E. coli. Food and Nutrition Sciences, University of Ghana, Legon. Food Science and Nutrition 335094(3):693-698. http://doi.org/10.4236/FNS.2012.35094

Akwuobu CA, Oboegbulem SI, Ofukwu RA (2010). Characterization and antibiogram of local isolates of Campylobacter species from chicken in Nsukka area, Southeast Nigeria. American European Journal of Sustainable Agriculture 4:117-121.

Anonymous (2003). Directive 2003/99/EC of the European Parliament and of the Council of 17 November 2003 on the monitoring of zoonoses and zoonotic agents, amending Council Decision 90/424/ EEC and repealing Council Directive 92/117/EEC. European Commission, Brussels.

Aworh MK, Kwaga J, Okolocha E, Mba N, Thakur S (2019). Prevalence and risk factors for multi-drug resistant Escherichia coli among poultry workers in the federal capital territory, Abuja, Nigeria. PLoS One 14(11):e0225379. https://doi.org/10.1371/journal.pone.0225379

Braide W, Adeleye SA, Ohanusi I, Ibegbulem CR, Mike-Anaosike EE, Madu LC (2017). Incidence of Campylobacter species in poultry products and beef sold in Owerri, Imo State, Nigeria. EC Microbiology 10(4):147-155.

Burgess F, Little CL, Allen G, Williamson K, Mitchell RT (2005). Prevalence of Campylobacter, Salmonella and Escherichia coli on the external packaging of raw meat. Journal of Food Protection 68(3):469-475. https://doi.org/10.4315/0362-028x

Center for Disease Control and Prevention (CDC) (2010). Campylobacter. General information, Department of Health and Human Services, Division of Foodborne, bacterial and Mycotic Diseases Atlanta. www.cdc.gov/nczved/division/afbmd/diseases/campylobacter

Chah KF, Ugwu IC, Okpala A, Adamu KY, Alonso CA, Ceballos S, Nwanta JA, Torres C (2018). Detection and molecular characterization of extended-spectrum $\beta$-lactamase-producing enteric bacteria from pigs and chickens in Nsukka, Nigeria. Journal of Global Antimicrobial Resistance 15:36-40. https://doi.org/ 10.1016/j.jgar.2018.06.002

CLSI (2010). Performance standards for antimicrobial susceptibility testing: Twentieth information. Supplement M100S20 USA, Wayne, PA.

Cokal Y, Caner V, Sen A, Cetin C, Telli M (2011). The presence of Campylobacter jejuni in broiler houses: Results of a longitudinal study. African Journal of Microbiology Research 5:389-393. https://doi.org/10.5897/AJMR10.809 
Colles FM, Cain RJ, Nickson T, Smith AL, Roberts SJ, Maiden MCJ, Lunn S, Dawkins MS (2016). Monitoring chicken flock behaviour provides early warning of infection by human pathogen Campylobacter. Proceedings of the Royal Society of Biological Sciences 283:2015-2323._https://doi.org/10.1098/rspb.2015.2323

DHHS (2010). Extra label drug use in animals. Department of Health and Human Services, Food and Drug Administration, Center for Veterinary Medicine. Federal Register 6:369.

El-Enbaawy MI, Yousif AA (2006). B-Lactamase gene in multi-drug resistant clinical bacterial isolates from Egyptian food animal species. Arab Journal of Biotechnology 9:71-82.

Food Standards Agency (FSA) (2014). A microbiological survey of Campylobacter contamination in fresh whole UKproduced chilled chickens at retail sale-interim report to cover quarters 1-3. Food Standards Agency, London, United Kingdom http://www.efsa.europa.eu/en/efsajournal/doc/2105.pdf

Gundogan N, Avci E (2013). Prevalence and antibiotic resistance of extended-spectrum beta-lactamase (ESBL) producing Escherichia coli and Klebsiella species isolated from foods of animal origin in Turkey. African Journal of Microbiology Research 7:4059-4064.

Horner CS, Abberley N, Denton M, Wilcox MH (2013). Surveillance of antibiotic susceptibility of Enterobacteriaceae isolated from urine samples collected from community patients in a large metropolitan area, 2010-2012. Epidemiology and Infection 9:1-5. https://doi.org/10.1017/S0950268813000988

Humphrey TJ, Martin KW, Slader J, Durham K (2001). Campylobacter spp. in the kitchen: spread and persistence. Journal of Applied Microbiology 91:115S-120S. https://doi.org/10.1046/j.1365-2672.2001.01359.X

Jaja IF, Green E, Muchenje V (2018). Aerobic mesophilic, coliform, Escherichia coli, and Staphylococcus aureus counts of raw meat from the formal and informal meat sectors in South Africa. International Journal of Environmental Research and Public Health 15(4):819-824._https://doi.org/10.3390/ijerph15040819

Jovanovic CJ, BrankoviLazić I, Balti T, Jovanovi M, Đorđevi V, Teodorovi V, Velebit B (2020). The prevalence of four virulence genes in strains of Campylobacter jejuni isolated from broilers in Serbia. Veterinary Archive 90:39-45. https://doi.org/10.240099/vet.arhiv.0477

Kabir J, Umoh JU, Umoh VJ (2004). Veterinary drug use in poultry farms and determination of antimicrobial drug residues in commercial eggs and slaughtered chicken in Kaduna State, Nigeria. Food Control 15:3-10. https://doi.org/10.1016/S0956-7135(03)00020-3

Karikari AB, Obiri-Danso K, Frimpong EH, Krogfelt KA (2017). Multidrug resistant Campylobacter in faecal and carcasses of commercially produced poultry. African Journal of Microbiology Research 11(7):271-277. https://doi.org/10.5897/AJMR2016.8329

Levallois P, Chevalier P, Gingras S, Dery P, Payment P, Michel P, Rodriguez M (2014). Risk of infectious gastroenteritis in young children living in Quebec rural areas with intensive animal farming: results of a case-control study (2004-2007). Zoonoses and Public Health 61:28-38. https://doi.org/10.1111/zph.12039

Li J, Hao H, Dai M, Zhang H, Ning J, Cheng G, Shabbir MAB, Sajid A, Yuan Z (2019). Resistance and virulence mechanisms of Escherichia coli selected by enrofloxacin in chicken. Antimicrobial Agents and Chemotherapy 63:e01824-18. https://doi.org/10.1128/AAC.01824-18

Lindqvist R, Lindblad M (2008). Quantitative risk assessment of thermophilic Campylobacter spp. and crosscontamination during handling of raw broiler chickens: evaluating strategies at the producer level to reduce human campylobacteriosis in Sweden. International Journal of Food Microbiology 121:41-52. https://doi.org/10.1016/j.ijfoodmicro.2007.10.008

Luangtongkum T, Jeon B, Han J, Plummer P, Logue CM, Zang Q (2009). Antibiotic resistance in Campylobacter. emergence, transmission and persistence. Future Microbiology 4:189-200. https://doi.org/10.2217/17460913.4.2.189

Magajna BA, Schraft H (2015). Campylobacter jejuni biofilm cells become viable but non-culturable (VBNC) in low nutrient conditions at $4 \mathrm{C}$ more quickly than their planktonic counterparts. Food Control 50:45-50. https://doi.org/10.1016/j.foodcont.2014.08.022

Made D, Geuthner AC, Imming R, Wicke A (2017). Detection and isolation of Shiga-toxin producing Escherichia coli in flour in Germany between 2014 and 2017. Journal of Consumers Protection and Food Safety 12:245-253.

Magiorakos AP, Srinivasan A, Carey RB, Carmeli Y, Falagas ME, Giske CG, ... Monnet DL (2012). Multidrug resistant, extensively drug-resistant and pan drug resistant bacteria: an international expert proposal for interim standard definitions for acquired resistance. Clinical Microbiology and Infection 18:268-281. https://doi.org/10.1111/j.1469-0691.2011.03570.x 
Manges AR, Smith SP, Lau BJ, Nuval CJ, Joseph Eisenberg JNS, Dietrich PS, Riley LW (2007). Retail meat consumption and the acquisition of antimicrobial resistant Escherichia coli causing urinary tract Infections: a case-control study. Foodborne Pathogen and Diseases 4:419-431. https://doi.org/10.1089/fpd.2007.0026

McEvoy JM, Sheridan JJ, Blair IS, McDowell DA (2004). Microbial contamination on beef in relation to hygiene assessment based on criteria used in EU Decision 2001/471/EC. International Journal of Food Microbiology 92:217-225. https://doi.org/10.1016/j.ijfoodmicro.2003.09.010

Mpundu P, Mbewe AR, Muma JB, Zgambo J, Munyeme M (2019). Evaluation of Bacterial contamination in dressed chickens in Lusaka abattoirs. Front Public Health 7:19. https://doi.org/10.3389/fpubh.2019.00019

Mohamed-Yousif IM, Abu J, Abdul-Aziz S, Zakaria Z, Rashid A, Awad EA (2019). Occurrence of antibiotic resistant $C$. jejuni and E. coli in wild birds, chickens, environment and humans from OrangAsli villages in Sungai Siput, Perak, Malaysia. American Journal of Animal and Veterinary Sciences. https://doi.org/10.3844/ajavsp.2019

Moreno Y, Hernandez M, Ferrus MA, Alonso JL, Botella S, Montes R, Hernandez J (2001). Direct detection of thermotolerant Campylobacters in chicken products by PCR and in situ hybridization. Research Microbiology 152(6):577-582. https://doi.org/10.1016/s0923-2508(01)01232-3

NDVQPH (2010). Standard for the microbiological monitoring of meat, process hygiene and cleaning. National Directorate for Veterinary Quarantine and Public Health; Pretoria, South Africa.

Nwankwo IO, Faleke OO, Salihu MD, Musa U, Magaji A, Audu B, Ngulukun S (2017). Prevalence and molecular identification of Campylobacter species isolates from poultry and humans in Sokoto, Nigeria. Sokoto Journal of Veterinary Science 15:1-8. https://doi.org/10.4314/sokjvs.v15i4

Nwankwo IO, Salihu MD, Faleke OO, Magaji AA, Garba J (2018). Seasonal variation in prevalence and antimicrobial resistance of campylobacter species isolates from the feces of free-range chickens and humans in Sokoto, north western Nigeria. Animal Science Reporter (e-edition) 11(4):11-21.

Nsofor CA, Olatoye IO, Amosun EA, Iroegbu CU, Davis MA, Orfe LH, Douglas R, Call DR (2013). Escherichia coli from Nigeria exhibit a high prevalence of antibiotic resistance where reliance on antibiotics in poultry production is a potential contributing factor. African Journal of Microbiology Research 7(38):4646-4654. https://doi.org/10.5897/AJMR12.671

Obioha FC, Ezenduka E, Ukoha JC, Nwanta JA (2016). Assessment of cadmium (Cd) residues in organs and muscles of slaughtered pigs at Nsukka and environs in Enugu State, Nigeria. Journal of Veterinary Medicine and Animal Health 8:199-206.

Olayinka AT, Jimoh O, Ejembi J, Ige OT, Lamido Z, Ibrahim A, Aganabor V, Olayinka B (2020). Antimicrobial prescription pattern in a tertiary hospital. Sahel Medical Journal 23:103-8.

Qiongzhen L, Julie SS, Catherine ML (2004). The presence of Listeria, Salmonella, E. coli and E. coli O157:H7 in Bison carcasses during processing. Food Microbiology 21:791-799. https://doi.org/10.1016/j.fm.2003.12.006

Raji M, Adekeye J, Kwaga J, Bale J, Henton M (2007). Serovars and biochemical characterization of Escherichia coli isolated from colibacillosis cases and dead-in-shell embryos in poultry in Zaria-Nigeria. Veterinarsk Arhiv 77(6) 495-505.

Rodrigo S, Adesiyuna A, Asgaralia Z, Swanston W (2005). Prevalence of Campylobacter spp. on chickens from selected retail processors in Trinidad. Food Microbiology 22:125-131. https://doi.org/10.1016/j.fm.2004.03.008

Rosenquist H, Sommer HM, Nielsen NL, Christensen BB (2006). The effect of slaughter operations on the contamination of chicken carcasses with thermotolerant Campylobacter. International Journal of Food Microbiology 108:226-232. https://doi.org/10.1016/j.ijfoodmicro.2005.12.007

Schroeder CM, White DG, Meng J (2004). Retail meat and poultry as a reservoir of antimicrobial-resistant Escherichia coli. Food Microbiology 21:249-255. https://doi.org/10.1016/s0740-0020(03)00074-1

Sharma KP, Chattopadhyay UK (2015). Assessment of microbial load of raw meat samples sold in open markets of city of Kolkata. Journal of Agriculture and Veterinary Sciences 8:24-27.

Soufi L, Abbassi MS, Saenz Y, Vinue L, Somalo S, Zarazaga M, ... Torres C (2009). Prevalence and diversity of integrons and associated resistance genes in Escherichia coli isolates from poultry meat in Tunisia. Food Pathology and Diseases 6:1067-1073. https://doi.org/10.1089/fpd.2009.0284

Thrusfield M (2005). Veterinary epidemiology. $3^{\text {rd }}$ edition. Blackwell Science Limited, Oxford. pp 233.

Ukut IO, Okonko IO, Ikpoh IS, Nkang AO, Udeze AO, Babalola TA, Mejeha OK, Fajobi EA (2010). Assessment of bacteriological quality of fresh meats sold in Calabar metropolis, Nigeria. Electron Journal of Environment, Agriculture and Food Chemistry 9(1):89-100. 
Van den Bogaard AE, London N, Driessen C, Stobberingh EE (2001). Antibiotic resistance of faecal Escherichia coli in poultry, poultry farmers and poultry slaughterers. Journal of Antimicrobial and Chemotherapy 47:763-771. https://doi.org/10.1093/jac/47.6.763

Wang G, Clark CG, Rodgers FG (2002). Detection in Escherichia coli of the genes encoding the major virulence factors, the genes defining the O157: H7 serotype and components of the type 2 Shiga toxin family by multiplex PCR. Journal of Clinical Microbiology 40:3613-3619. https://doi.org/10.1128/JCM.40.10.3613-3619.2002

World Health Organization (WHO) (2017). Critically Important Antimicrobials for Human Medicine. 5th ed. Retrieved 2019 September 10 from http://www.apps. who.int

Yamazaki-Matsune W, Taguchi M, Seto K, Kawahara R, Kawatsu K, Kumeda Y, ... Tsukamoto T (2007). Development of a multiplex PCR assay for identification of Campylobacter coli, Campylobacter fetus, Campylobacter hyointestinalis subsp. hyointestinalis, Campylobacter jejuni, Campylobacter lariand Campylobacter upsaliensis. Journal of Medical Microbiology 56:1467-1473. https://doi.org/10.1099/jmm.0.47363-0

Zailani SAQ, Bello M, Raji MA, Kabir J, Yahuza SM (2016). Microbial evaluation of meat contact surfaces in red meat abattoirs of Bauchi State, North-Eastern Nigeria. Open Journal of Medical Microbiology 6:3-8. https://dx.doi.org/10.4236/ojmm.2016.61002

Zhang T, Wang CG, Lv JC, Wang RS, Zhong XH (2012). Survey on tetracycline resistance and antibiotic-resistant genotype of avian Escherichia coli in North China. Poultry Science 91:2774-2777. https://doi.org/10.3382/ps.2012-02453
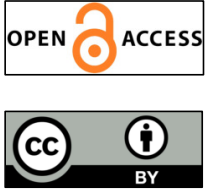

The journal offers free, immediate, and unrestricted access to peer-reviewed research and scholarly work. Users are allowed to read, download, copy, distribute, print, search, or link to the full texts of the articles, or use them for any other lawful purpose, without asking prior permission from the publisher or the author.

License - Articles published in Notulae Scientia Biologicae are Open-Access, distributed under the terms and conditions of the Creative Commons Attribution (CC BY 4.0) License.

(c) Articles by the authors; SHST, Cluj-Napoca, Romania. The journal allows the author(s) to hold the copyright/to retain publishing rights without restriction. 